4. Kopnina G. Speech manipulation. $6^{\text {th }}$ edition. Moscow : FLINTA, 2017. $170 \mathrm{p}$.

5. Latest Politics News [Electronic resource] - Access Mode: https://www.aol.com/?err=404\&err_url=https $\% 3 \mathrm{a} \% 2 \mathrm{f} \% 2 \mathrm{fwww}$. aol.com $\% 2 \mathrm{far}$ ticle $\% 2$ fnews $\% 2 \mathrm{f} 2019 \% 2 \mathrm{f} 09 \% 2 \mathrm{f} 11 \% 2 \mathrm{ftrump}-\mathrm{mr}$-tough-guy-bolton-

DOI https://doi.org/10.30525/978-9934-26-039-1-42

\title{
COLLOCATION AS A MINIMAL UNIT OF VOCABULARY ACQUISITION BUILDING IN ENGLISH LEARNING PROCESS
}

\author{
Zhelobytska T. V. \\ Senior Lecturer at Applied Linguistics, Comparative Philology \\ and Translation Studies Department, \\ Postgraduate Student at Applied Linguistics, Comparative Philology \\ and Translation Studies Department \\ National Pedagogical Dragomanov University \\ Kyiv, Ukraine
}

It is vitally important for learners to build a large vocabulary in the English language which they are studying. Various researchers have looked into the number of word families in different texts to see how big that vocabulary might need to be. A general rule of thumb for deciding how many words learners need in order to read a text without support is $98 \%$ and with support is $95 \%$. Various kinds of texts have different vocabulary loads. Canadian linguist Nation $[14$, p. 59-82] found that $98 \%$ is reached for newspapers, novels, and university-level texts at 8,000-9,000 word families plus proper nouns. Another Associate Professor in Applied Linguistics Coxhead [4, p.34] found the same load of 8,000-9,000 plus proper nouns at $98 \%$ coverage for novels that might be read at the high school level, such as Clepto, Split by Lori Weber (Canadian English, CE), The Bell Jar by Sylvia Plath (American English, AE), Pride and Prejudice by Jane Austen (British English, BE). A study of movies by Webb $\&$ Rodgers [18, p.420], for example, found that $95 \%$ coverage was reached at 3,000 word families plus proper nouns and marginal words. The authors also found that $98 \%$ was reached at 6,000 word families plus proper nouns and marginal words. Dang and Webb [7, p. 68] looked at academic spoken English and found just over $96 \%$ coverage with 4,000 word families plus proper nouns, but $98 \%$ coverage at 8,000 word families plus proper nouns and marginal words. In another study, Coxhead and Walls [5, p. 62] developed a corpus of 
TED Talks (www.ted.com) and found that $95 \%$ was reached at 5,000 plus proper nouns, and 8,000-9,000 word families plus proper nouns were needed to reach $98 \%$. Their finding suggests that TED Talks are closer in nature to academic writing. You can find out how many words learners know or can recognize using Nation's Vocabulary Size Test [7, p.70] (a copy of the test is on Tom Cobb's website, the Compleat Lexical Tutor (URL: www.lextutor.ca)).

Teachers and learners need to make clear decisions about which words they will focus on. They can make these decisions by looking at the frequency of words by concentrating on the most frequent words in the language they are learning (for more on frequency in vocabulary, see [11]; for a new General Service List of the most frequent words in English see [1]. Teachers might take into account word lists for their specialized subject area or general academic word lists such as the Academic Word List of Coxhead (URL: https://www.wgtn.ac.nz/lals/resources/academicwordlist). With the expansion of the size of vocabulary, many problems arise concerning the proper usage of a word in context, among which is collocation. Collocation is one of the most important aspects of knowing a word. In order to deepen the understanding of a word, English students must know its collocations [8, p. 32].

The aim of the present research is to define a collocation as a minimal unit in vocabulary acquisition building and to outline its primary importance for English Learners (ELs) in mastering English.

The objectives are: to look into definitions of collocation; to inquire into the importance of collocations usage; to provide some recommendations for the teaching and learning process of collocations. The basic concern that consistently ran throughout the research was the importance of admitting the collocations usage necessity as the minimal units in the English Learning Process (ELP) as well as in the English Teaching Process (ETP), no matter what variant of English it is (Canadian English (CE), American English (AE) or British English (BE)). Mastery of vocabulary can contribute to the constructing of correct collocations usage as a part of necessary English vocabulary acquisition building. Collocation could be presented as a universal linguistic phenomenon.

The basic source for this research has been the recent foreign language studies on definition of collocations in the English Learning Process (ELP). Print media that has been used consists of language studies journals, general linguistic information conducted in various papers on Language Studies or Applied Linguistics. The electronic media that has facilitated the research includes online articles, various vocabularies and dictionaries of 
$\mathrm{CE}, \mathrm{AE}$, and $\mathrm{BE}$ (Canadian Collocation Dictionary: URL: https://collocations.enacademic.com/ 2390/Canadian; The American Heritage of the English Language: URL:https://www.ahdictionary.com; Oxford Collocations Dictionary for Students of English: URL:https://www.freecollocation.com), TED talks videos (URL:https://www.ted.com), advanced online scientific publications, free corpora on the Internet: The Strathy Corpus of Canadian English (URL: https://www.english-corpora.org/can/), Corpus of Contemporary American English (URL: https://www.english-corpora.org/coca/, British National Corpus (URL: http://www.natcorp.ox.ac.uk),).

The structural method providing brief insights into explanation of the collocation definitions (a definitive analysis) and their importance of admitting the collocations as the minimal units (a distributive analysis) in ETP as well as in ELP. The contrastive method let us to compare / contrast and determine the main influenced points of $\mathrm{CE}, \mathrm{AE}$, and $\mathrm{BE}$ collocations and complete the various ways of teaching and learning them specifically and separately right in each variant of English. While we view 'collocation' from a multi-disciplinary perspective, we adopt a technical definition of what linguistic analysis is, specifically an analysis that employs constructs from the field of linguistics that are designed to study English language (CE, AE, $\mathrm{BE}$ ) as a primary focus of inquiry. The research synthesis contains the composition and combination of proper collocation usage in real oral speech and in written contexts according to clear understanding of its separate parts and elements as the one totally full form of foreign language. All the stages involve induction and deduction to make the relevant conclusions. In this research, we address the issue of the interconnection between collocations and quality of ETP and ELP for ELs, and we recommend brief solutions for identifying collocations in CE, $\mathrm{AE}, \mathrm{BE}$ as soon as possible via modern online resources.

Conclusively, the methodology used for this academic research is simple being profound and scientifically approved. Moreover, this work has been challenging considering the fact that there is a serious dearth of original English (CE, AE, BE) printed resources in Ukraine and the research was based only on international English sources and original materials.

The present research explores and represents collocation as the minimal unit in vocabulary acquisition building in 2 stages: 1) specifying the definition of collocation; and 2) proving the importance of collocations knowledge.

The Definition of Collocation: The idea of 'collocation' was first put forward by J. R. Firth in 1957. Although the word is used widely, scholars' opinions are divided when it comes to the meaning of collocation. Robins 
argues that collocation is «the habitual association of a word in a language with other particular words in sentences» [15, p. 64]. Robins' understanding of collocation agrees with Firth's and Halliday and Hasan's. In Cohesion in English, Halliday and Hasan argue that collocations a means of cohesion is «the co-occurrence of lexical items that are in some way or other typically associated with one another, because they tend to occur in similar environments.» [13, p. 317]. Collocation is a kind of syntagmatic relation. We have to make a distinction on the one hand between free combinations and collocation and on the other between 'collocation' and 'idiom'. Just as Sinclair says, «The principle of idiom is that a language user has available to him/her a large number of semi-pre-structured phrases that constitute single choices, even though they might appear to be analyzable into segments» [16, p. 110].

To summarize, collocation refers to the frequent co-occurrence and mutual expectation of some words which appear more often than by chance. In this sense, collocation can be called a restricted combination, which exists between a free combination and an idiom and has semantic transparency.

The Importance of Collocation: Free combinations are easy to acquire because they come from the structure of extra-linguistic reality such as dark night and blue sky, etc. They are «manifestly related to the referential and substantial meaning of the words concerned» [15, p. 56]. Richard summarizes what is meant by mastering a word: 1) knowing the frequency of the word in oral and written language; 2) knowing the grammatical patterns of the word; 3 ) knowing its associated network with other words [14, p.183]. Collocation is a universal linguistic phenomenon. It is only logical to say that none of the natural languages are free of collocation. In fact, «words seldom occur in isolation» $[17$, p. 30]. Wallace in Teaching Vocabulary emphasizes that to know a word in a target language «may mean the ability to use it with the words it correctly goes with, i.e. in the correct collocation [...]» [17, p. 27]. Most English words are polysemous, i.e. having more than one meaning. As a result, difficulty arises when it comes to the exact meaning of a word in a given context. It is pointed out in Oxford Collocations Dictionary for Students of English (URL:https://www.freecollocation.com) that «the precise meaning in any context is determined by that context: by the words that surround the combine with the core word-by collocation.»[6, p.VII].

How to Teach and Learn Collocation: The consciousness of the importance of collocation in the learning of a new word will enable students to find the proper collocation for every word they learn. The influence of French on Canadian English could be studied deeply as well because the new Canadian collocations with French meanings appear every day. All regions of Canada are institutionally bilingual. Every citizen has the right to be served in 
either French or English by government agencies, tried in either language in federal courts, informed in either language in public announcements on radio and television, and advised in both languages on product labels, tax forms, and all other official documents [9, p. 23]. In percentages, the mother-tongue groups are proportioned as follows: 59.2\% speak English, $22.7 \%$ speak French, $0.4 \%$ are English-French bilinguals, and $17.5 \%$ have a mother tongue neither English nor French. The French-English bilinguals in these figures count only «true bilinguals», rare individuals who learned both languages from birth [19, p. 3].

Canadian English Vocabulary Specificity and its Future Prospects: Even before Canada had a significant and widespread population, many distinctive features of the Canadian vocabulary came into being. Explorers and adventurers learned the names of all the places they visited from the natives, and in many cases the native names stuck [20, p. 153]. Indigenous plants and animals usually kept their native names. One obvious area for vocabulary development comes from terms for technological innovations. More teachers have realized the importance of teaching CE vocabulary, but as for how to teach such vocabulary there are still different arguments. Some teachers hold the view that since vocabulary can be learnt through extensive listening and reading, we don't need to spend much time teaching vocabulary explicitly in class. This is a great misunderstanding. Explicit vocabulary teaching is important. Part of class should be devoted to the explicit teaching of such vocabulary. Students should be encouraged to listen to or read genuine $\mathrm{CE}$ written by native speakers. Nowadays, there are many excellent dictionaries of $\mathrm{CE}, \mathrm{AE}$, and $\mathrm{BE}$ collocations (Canadian Collocation Dictionary: URL: https://collocations.enacademic.com/2390/Canadian; The American Heritage of the English Language: URL:https://www.ahdictionary.com; Oxford Collocations Dictionary for Students of English: URL:https://www.freecollocation.com).

Nowadays, there are many free corpora on the Internet: The Strathy Corpus of Canadian English (URL: https://www.englishcorpora.org/can/), Corpus of Contemporary American English (URL: https://www.english-corpora.org/coca/), British National Corpus (URL: http://www.natcorp.ox.ac.uk).

In conclusion, correct and idiomatic use of words depends largely on the mastery of their typical collocational behavior. In order to learn new words well and deepen understanding, both students and teachers of English should pay more attention to collocation and be aware of the importance of collocation in the acquisition of a word. 
Conclusions: The present research shows the results of exploration and presentation the collocations as the minimal units in vocabulary acquisition building for different variants of English (CE, AE, and $\mathrm{BE}$ ). Collocation is highlighted as a universal linguistic phenomenon typical of all the languages. The results of this research show the importance of admitting the collocations usage necessity as the minimal units in English Learning Process as well as in English Teaching Process. It is important to know the historical aspects of studied language with its reflection in originally based collocations.

Some recommendations for the teaching and learning processes of collocations are finally provided in order to improve and refresh modern English studies for students of linguistics / philology departments. They are: teach / learn English via modern $\mathrm{CE} / \mathrm{AE} / \mathrm{BE}$ sources; emphasize on collocations structure and meaning during English Teaching and Learning vocabulary; pay a special attention to difference in similar collocations among various variants of English (for instance, as presented for $\mathrm{CE} / \mathrm{AE} / \mathrm{BE}$ in this paper); give preference to teaching / learning materials in native English; encourage students to read and listen to genuine $\mathrm{CE} / \mathrm{AE} / \mathrm{BE}$ written by native speakers; make use of online dictionaries, free corpora, and the Internet rich materials on a regular basis.

Conclusively, the research on collocations as the minimal units of vocabulary acquisition building in the English teaching and learning process has its profound contribution into the necessary and important modern English knowledge. The prospects for further study may cover building of a digital dictionary of most frequent collocations in Canadian English, American English, and British English.

\section{References:}

1. Brezina, V. \&Gablasova, D. (2013) Is there a core general vocabulary? Introducing the new general service list. Applied Linguistics. Advanced online publication. doi:10.1093/applin/amt018

2. Cartwright, Don (1988) Language policy and internal geopolitics: the Canadian situation. Language in Geographic Context, ed. Colin H. Williams. Clevedon: Multilingual Matters. 238-266.

3. Coxhead, A. (2000) A new academic word list. TESOL Quarterly, 34, 213-238. doi:10.2307/3587951.

4. Coxhead, A. (2012) Researching vocabulary in high school English texts: «The Bell Jar» and more. English in Aotearoa, 78, 34-41.

5. Coxhead, A. \& Walls, R. (2012). TED Talks, vocabulary, and listening for EAP. TESOLANZ Journal, 20, 55-67. 
6. Crowther, J. (2003) Oxford Collocation Dictionary for Students of English. Beijing: Foreign Language Teaching and Research Press.

7. Dang, T. \& Webb, S. (2014) The lexical profile of academic spoken English. English for Specific Purposes, 33, 66-76. doi:10.1016/j.esp.2013.08.001.

8. Duan M., Qin X. (2012) Collocation in English Teaching and Learning. Theory and Practice in Language Studies, Vol. 2, No. 9, pp. 1890-1894, September 2012, ACADEMY PUBLISHER Manufactured in Finland, doi:10.4304/tpls.2.9.1890-1894.

9. Gold E. \& McAlpine J. (2010) Canadian English: A Linguistic Reader: Occasional Papers Number 6. Strathy Language Unit, Queen's University, Kingston, Ontario (p. 241), p. 2-38.

10. Joy, Richard J. (1992) Canada's Official Languages: The Progress of Bilingualism. Toronto: University of Toronto Press.

11. Nation, I. S. P. (2013) Learning vocabulary in another language, 2nd ed. Cambridge, England: Cambridge University Press.

12. Nation, P., \&Beglar, D. (2007) A vocabulary size test. The Language Teacher, 31(7), 9-13.

13. Halliday, M. A. K., Hasan. (2001) Cohesion in English. Beijing: Foreign Language Teaching and Research Press.

14. Richards, J. (1985) Lexical Knowledge and the Teaching of Vocabulary. In Richards, J. (ed.), The Context of Language Teaching. Cambridge: Cambridge University Press.

15. Robins, R. H. (2000) General Linguistics (Ed.4). Beijing: Foreign Language Teaching and Research Press.

16. Sinclair, J. (1999) Corpus, Concordance, Collocation. Shanghai: Shanghai Foreign Language Education press.

17. Wallace, M. J. (1982) Teaching Vocabulary. London: Heinemann Educational Books.

18. Webb, S. \& Rodgers, M. P. H. (2009) The lexical coverage of movies. Applied Linguistics, 30(3), 407-427. doi:10.1093/applin/amp010.

19. Weinreich, Uriel (1967) Languages in Contact. The Hague: Mouton.

20. Woods, Howard B. (1993) 'A synchronic study of English spoken in Ottawa: Is Canadian English becoming more American?' In Focus on Canada, ed. Sandra Clarke. Philadelphia: John Benjamins. P. 151-178. 